\title{
Chytridiomycosis in Asian Amphibians, a Global Resource for Batrachochytrium dendrobatidis (Bd)
} Research

Gayathri Sreedharan and Karthikeyan Vasudevan"(i)

\begin{abstract}
Chytridiomycosis is an emerging infectious disease affecting amphibians globally and it is caused by the fungal pathogen Batrachochytrium dendrobatidis $(B d)$. Chytridiomycosis has caused dramatic declines and even extinctions in wild amphibian populations in Europe, Australia, Central and North America. Spanning over two and a half decades, extensive research has led to discovery of epizootic and enzootic lineages of this pathogen. However, the $B d$-amphibian system had garnered less attention in Asia until recently when an ancestral $B d$ lineage was identified in the Korean peninsula. Amphibians co-exist with the pathogen in Asia, only sub-lethal effects have been documented on hosts. Such regions are 'coldspots' of infection and are an important resource to understand the dynamics between the enzootic pathogen$B d$ and its obligate host-amphibians. Insights into the biology of infection have provided new knowledge on the multi-faceted interaction of $B d$ in a hyperdiverse Asian amphibian community. We present the findings and highlight the knowledge gap that exists, and propose the ways to bridge them. We emphasize that chytridiomycosis in Asia is an important wildlife disease and it needs focussed research, as it is a dynamic front of pathogen diversity and virulence.
\end{abstract}

\section{Introduction}

Amphibians are declining throughout the world and one of the major drivers of this is an ancient, non-hyphal aquatic fungus ${ }^{1,2}$. Batrachochytrium dendrobatidis $(B d)$ is a chytridiomycetes fungal pathogen that infects only amphibian hosts ${ }^{3}$. In the early part of the twentieth century, frog dieoffs in pristine and protected areas in Central America, the Carribean and Australia triggered an alarm. These were called 'enigmatic declines' as there was no evidence of a causal factor, until it was discovered that a chytrid fungus was responsible for causing mortality in frog populations. As reports of chytridiomycosis emerged from several continents, the true magnitude of the impact it had caused on frog populations was understood. This event earned an opprobrious title as 'Amphibian Apocalypse' and it has been "one of the worst wildlife diseases that has emerged in the twentieth century in terms of the number of species impacted and also its propensity to drive the species to extinction" 4 . Until now, $B d$ has been linked to population declines in almost 500 species amphibians, with over 90 extinctions globally, across its three extant Orders ${ }^{5}$.

In amphibians, skin is an organ of respiration, thermoregulation, and exchange of electrolytes with their environment, and therefore, skin infections could lead to fatality in them. The chytrid fungus has a uni-flagellated, ophisthokont zoospore that swims with a characteristic 'whiplash' movement in the aquatic environment ${ }^{6}$. Once this zoospore finds suitable substrates like the keratinous layer of the amphibians' skin, it develops a thallus and grows in the stratum corneum of the epidermis ${ }^{3,6}$. Here it forms a zoosporangium that increases in size and develops discharge papillae that allows motile zoospores
${ }^{1}$ CSIR-Centre for Cellular and Molecular Biology, Hyderabad, India. *karthik@ccmb.res.in 
to exit the host and latch on to other hosts. The susceptible host finally dies due to an osmotic shock within a maximum of 35 days after onset of infection ${ }^{7}$. This fungus belongs to the family Chytridiomycota which is an ancient fungal family. Most members of this family of fungi are not pathogenic ${ }^{8}$.

Since chytridiomycosis is classified as an emerging infectious disease (EID), many theories have been offered to explain the emergence of the disease. A dominant theory posits that disequilibrium between the host, pathogen, and environment causes EIDs to emerge 9 . The factors contributing to the disequilibrium could be several, including a change in abiotic conditions that might have altered host-pathogen interactions. The emerging nature of the disease has piqued scientific investigations globally, as disease spread of such nature is rare in wildlife. Two major hypotheses were advanced to explain the emergence of chytridiomycosis ${ }^{10}$. The novel pathogen hypothesis (NPH) states that the disease emerged independently in different continents as a result of global trade and infects naïve hosts. This has been validated by studies that showed epizootic episodes of $B d$ on the global trade routes ${ }^{2,11-13}$. Genetic studies using multi-locus sequence typing (MLST) suggest no genetic structuring or pronounced genetic diversity in the samples of $B d$ collected $^{14}$. This has been attributed to recent expansion from a singular infection epicentre. The endemic pathogen hypothesis (EPH) posits that $B d$ is a longstanding commensal on the amphibian skin microbiome and the most recent shifts in climate, habitats and even host factors like, loss of resilience might have distorted the equilibrium between the host and the commensal. This hypothesis receives support from the discovery of $B d$ from skin swabs of ancient museum specimens of amphibians from South America and Africa ${ }^{10}$. Over time, evidence has been assembled to join the dots between sudden emergence of chytridiomycosis, the dynamics of amphibian populations and climate change impacts ${ }^{15,16}$. A strong support for this theory has come from Litoria wilcoxii populations that showed varied responses to $B d$ infection across an altitudinal or latitudinal range and across seasons ${ }^{17-19}$. Such a continuum of host responses to various biotic and abiotic factors suggest that EPH might be a tenable explanation for $B d$ pathogenesis on frogs ${ }^{2,20}$. However, the most recent evidence from 234 chytrid isolates acquired over a span of 20 years from different continents re-defined our understanding of the origin of the pathogen. This study revealed a distinct $B d$ ASIA- 1 lineage.
This lineage with high genetic diversity from Asia might be the ancestral to $B d$ GPL (Global Panzootic Lineage), $B d$ ASIA 2/Bd BRAZIL and $B d$ $\mathrm{CAPE}^{21}$. Asia has been a major exporter of frog legs which might have spread $B d$ into other continents, and this explains the possible origin of $B d$ from Asia.

There is enormous disparity in our knowledge on chytridiomycosis in different parts of the world. The continents with $B d$ hotspots such as, the Americas and Australia, have channelled more resources and published work, which has led to extensive standardisation of diagnostic and monitoring protocols for $B d$ infections in wild and captive frogs. In Africa and Asia, mortalities have been poorly or not documented. These efforts led to a Global $B d$ mapping project where regional surveillance efforts have been compiled in the form of an interactive database $\mathrm{e}^{22}$. These countries with $B d$ hotspots have collaborated to acquire and archive cultures for research on $B d$. The European Union project RACE (Risk Assessment for Chytridiomycosis to European Amphibian Diversity) is a good example of this, and it has standardised protocols for culturing $B d$ championed by Joyce Longcore ${ }^{23}$. This effort witnessed a vast collective of researchers working across 5 continents, 23 countries and 62 extant amphibian species $^{24}$.

First reports of chytridiomycosis from Asia came as late as 2008 from Japan ${ }^{25}$. In Giant Japanese Salamander, Andrias japonicas a museum specimen from 1902 had $B d$ on its skin ${ }^{26}$. After this, a series of efforts were made to document prevalence of $B d$ infection from different parts of Asia ${ }^{27-38}$. Lethal outbreak of the infection has so far not been recorded from Asia and therefore, it is referred to as a 'coldspot' of $B d$ infection. The reason for tolerance of hosts to $B d$ infections in coldspots is not clearly understood. With more than 500 amphibian species and over $60 \%$ endemic to South Asia, this region presents an important region for studies on Chytridiomycosis. This review is an attempt at recapitulating previous studies on the $B d-$ frog system from Asia to acknowledge the existence of certain crucial research gaps and also emphasize the need for a directed and concerted effort in these 'coldspots' to tackle an important wildlife pathogen. In this review, we have tried to understand the course of this host-pathogen system in Asia in the context of parallel advances in this field across other parts of the world, which makes this review different from some previous reviews on chytrid from Asia. This puts our work in perspective and offers wider opportunities to design future trajectory 
of this dynamic host-pathogen system in Asian coldpots.

\section{Why 'Coldspots' of Chytridiomycosis?}

Coldspots of infection are geographic regions with abundant host population that do not have the pathogen or areas where the pathogen is present in high or low prevalence with low loads of infection per host ${ }^{39}$. Initial studies on chytridiomycosis were almost singularly focussed on the frog population that experienced mortalities. This effort did not reveal the existence of genetic structuring in the pathogen. Goka et al. ${ }^{26}$ study was among the first to highlight that genetic homogeneity observed in $B d$ haplotypes was due to sampling from the epizootic fronts of the disease. As the $B d$ sampling expanded to represent different regions including coldspots, many endemic strains were revealed. Interestingly, sampling in 'coldspots' suggested that there were some unexpected patterns, such as the existence of endemic strains restricted to certain continents, and the panzootic lineage was found globally. The first extensive study in Asia (along with Papua New Guinea), involved sampling 3363 amphibians belonging to three orders (Anurans, Caudates and Gympniophona) that were swabbed for $B d^{40}$. It pointed out low prevalence $(2.2 \%)$ of $B d$ and majority of the infection loads lower than the threshold of infection for frogs ${ }^{41}$. The areas surveyed for $B d$ infection ${ }^{40}$ were chosen based on a species distribution model (SDM) of global geographic distribution ${ }^{42}$.

The key findings from the extensive $B d$ surveillance effort from Asia prompted three major hypotheses: (1) $B d$ GPL has not yet emerged or dispersed into Asian frogs; (2) $B d$ in Asia is endemic, therefore, native amphibians have coevolved and are not impacted fatally; (3) various biotic and abiotic factors in Asian countries are unfavourable for $B d$ to emerge as a pathogen. The spatio-temporal pattern in Asia seems to deviate from the expectation of an emerging pathogen. A wave-like pattern of spread is expected when $B d$ infects a naïve amphibian population ${ }^{41,43}$. It will result in immediate impacts, such as dwindling of frog populations and eventually a collapse of the amphibian community. It will advance in the direction of more susceptible host species in suitable climatic regimes $^{41,43}$. Infected frog populations in Asia do not follow this geographic pattern of spread. Museum specimens from 1902 revealed $B d$, suggesting that it could have been present in Asian frog populations since long ${ }^{26}$. However, museum specimens representing a geographic area or a period have not been studied in Asia, so the time since $B d$ infections for Asian frog populations is not known. For the second hypothesis, recent evidence reveals that several haplotypes of $B d$ are involved in causing asymptomatic infection in frogs ${ }^{26,28,37}$. The third hypothesis about biotic and abiotic factors might be difficult to test, because of the dearth in understanding of the pathogen in Asia. SDMs predict suitable areas for the pathogen to thrive and infect frogs in Asia. There are speculations that in coldspots, 'Ghosts of Infection Past' could have played a role. This means the community of frogs have resisted and recovered from epizootic waves of $B d$ infection in the historical past ${ }^{39}$. Coldspots with a high prevalence and low infection loads, imply stable coexistence between the host and pathogen ${ }^{29}$. Therefore, coldspots of infection should be investigated to gain an in-depth understanding of the limits of pathogen virulence ${ }^{39}$.

\section{Evolutionary History of $\mathbf{B d}$ and the Importance of Studies from Coldspots}

The debate on the origin of $B d$ centred around Africa $^{12}$, $\operatorname{Japan}^{26}$, East Asia ${ }^{29}$, South America ${ }^{44}$ and North America ${ }^{45}$. There was ambiguity on the time of divergence of $B d$ from the most recent ancestor. Age of $B d$ was estimated to range from 100 years ${ }^{46}$ to 25,000 years ${ }^{47}$. Bd ASIA-1 isolated from Korea had the signatures of an ancient lineage and was basal to all the other known lineages in the global phylogeny. $B d \mathrm{CH}$ (Switzerland) grouped with the clade belonging to $B d$ ASIA-1 and a lineage $B d$ ASIA-2 that was isolated from introduced North American Bullfrogs in Korea. It was closely related to $B d$ BRAZIL, and hence it was named as $B d$ ASIA-2/BRAZIL. These inferences were made using high-throughput sequencing of whole mitogenomes of the $B d$ isolates to establish the phylogenetic relationship between the various lineages ${ }^{21}$. Seven South Korean frogs that yielded the isolates of $B d$ ASIA-1 in this study showed no clinical infections. This was noteworthy, because it points at the need for focussed surveys in Asia where there are no mortalities, because there could be infection by hitherto unknown enzootic $B d$ lineages. This work constitutes an important landmark in global chytrid research, as it established the link between field surveys and culturing chytrid from coldspots of infection to answer the most basic question that has eluded us for nearly 20 years - where did this pathogen originate? 
Extensive use of gene sequences to diagnose infections and draw phylogenies of $B d$ led to a thorough investigation of the limitations of different genetic markers employed. The use of ITS (Internal Transcribed Spacer region), a nuclear genome element for phylogenetic studies, resulted in ambiguous classification of the isolates, though it is touted as an excellent diagnostic marker for $B d^{21}$. Mitogenomes have been used to establish phylogenetic relationships and ascertaining lineages of $B d$. $B d$ GPL diverged from the other lineages 120 years ago which coincided with the global expansion of amphibian pet trade, food and medicinal purposes ${ }^{21}$. Some of these amphibians might have been infected with the enzootic lineage in Asia and spread into the naïve frog populations in America and Australia.

There is evidence of sexual reproduction in $B d^{48}$. Hybridization between lineages upon contacting is possible and it has been reported ${ }^{21,49,50}$. O'Hanlon et al. ${ }^{21}$, has also reported three hybrid genotypes, two of them between $B d$ GPL and $B d$ CAPE from South Africa. In 2019, Byrne et al. ${ }^{50}$ reported a new diverged lineage of $B d$ from Asia, named $B d$ ASIA-3 which was commonly reported in samples from Philippines, Indonesia and parts of China. In these countries, $B d$ ASIA- 3 is known to co-occur with $B d \mathrm{GPL}^{50}$. In this study, a sequence from the Philippines could not be classified into either of the two lineages. However, there were no signs of hybridization, and it was concluded to belong to an early branching event caused by a new lineage from $\mathrm{Asia}^{50}$.

With over 7800 amphibians described till date ${ }^{21,51}$, approximately 700 species were infected with $B d$ out of only 1300 species screened ${ }^{22}$, and a thriving global trade of live frogs involving over 450 species $^{52-55}$, it is huge a challenge to tease apart the cryptic diversity of the pathogen in Asia, where two new lineages have been identified in the last two years! This signals Asia as a coldspot of infection and amphibians here should be monitored for new and hybrid chytrid lineages. These could be potentially new strains that are more virulent than the parent lineages ${ }^{56}$. Since this region might harbour hybrid lineages, it should be the focus for intensive monitoring; as they might serve as spawning grounds for potent $B d$ strains to evolve with stronger pathogenic traits than their parents and cause outbreaks in naïve frog populations globally. We already know that the transition from colonising an amphibian to actually causing a disease is context-dependent ${ }^{57-59}$. Therefore, individual and population level outcomes of $B d$ infections might depend on various factors irrespective of whether the infection is caused by an enzootic or panzootic lineage. All these factors make future studies in coldspots indispensable to understand the biology of this amphibian-specialist pathogen.

\section{Current Understanding of Chytridiomycosis from Asian Coldspots}

Research investments on chytridiomycosis in coldspots ranges from, no knowledge of the pathogen in amphibian populations to regular monitoring of the host, the pathogen, and culturing of $B d$ isolates. Disparity in research investments has caused large gaps in knowledge about the dynamics of the pathogen. In order to bridge these gaps, they need to be highlighted and filled in due course of time. We present the case for India and the countries that it shares borders with. This geographic area is located at the intersection of global biogeographic realms. As a consequence of this, the phylogenetic richness of amphibians is high. In India alone, there are 406 species of frogs (Anurans), 39 known species of caecilians (Gymnophiona) and 2 known species of salamanders (Caudata) ${ }^{60}$. Thirty five species of caecilians are endemic to India, making it a hotspot of caecilian diversity ${ }^{61}$. Amphibian biodiversity in this region had not been surveyed for chytridiomycosis until recently. There has been no amphibian die off events in India except for some incidents linked to unknown causes ${ }^{76}$. The first report of chytridiomycosis came in 2011 from the Western Ghats, where 180 frogs belonging to the endemic genera Indirana were screened for Ranavirus (a viral disease affecting amphibians) and chytridiomycosis ${ }^{33}$. While their survey showed all samples negative for Ranavirus, one sample from Indirana brachytarsus, was tested positive for $B d$. The infection load reported using quantitative Polymerase Chain Reaction (qPCR) assay for $B d$ was low (ranged from 0.3 to 3 ) and the frog did not show any clinical symptoms of chytridiomycosis. This was followed by surveys by Dahanukar et al. ${ }^{34}$ in the northern Western Ghats, where samples were screened for $B d$ using nested PCR and qPCR from swab and tissue samples from Nyctibatrachus humayuni, Indirana leithii, and Raorchestes bombayensis which were also subjected to histopathological examination. In this study, 32 frogs belonging to 5 genera (Nyctibatrachus humayuni, Indirana leithii, Raorchestes bombayensis, Euphlyctis cyanophlyctis, and Fejervarya caperata) were swabbed and 8 tested positive for $B d$ infection. The haplotypes identified on the frogs were closely related 
to Asia-specific haplotypes like $\mathrm{B}$ and $\mathrm{K}$ from Japan $^{27}$ and CN30 from China ${ }^{26}$. An interesting observation made through this study was- $B d$ positive frogs showed no symptoms of infection, except for one $N$. humayuni that showed symptoms such as, browning of skin and lesions on the limbs. A common, albeit mild symptom that was recorded in all the three species was inflammation on the digits. However, the load of infection on the frogs was low. In 2015, around 497 frogs were sampled across the entire Western Ghats, which spans a wide altitudinal, latitudinal range ${ }^{36}$. They found $8 B d$ positive from 497 samples. This study documented a higher infection load ranging from 6 to 785 zoopsore equivalents as opposed to 0.3 to $3^{33}$ and 2 to $13^{34}$. They recorded strains which were identical to that of the previous studies recorded from India, and were closely related to other recorded Asian strains. This suggested an endemic clade of $B d$ from Asia involved in infections of Indian amphibians with a low prevalence, low individual load of infection. However, it was not clear how widespread the disease was.

Between 2012 and 2017 extensive $B d$ surveys were made from all the biodiversity hotspots in India by Mutnale et al. ${ }^{37}$. A large number of frogs from 147 locations across these hotspots, to be the first study from the country, to screen 9 families, 33 genera and 111 species of frogs from these areas. They recorded 158 samples with $B d$ infection out of the 1870 swabs collected, and they assessed ITS region haplotype diversity. Out of 57 haplotypes retrieved 46 were unique to India. Some frogs had more than one haplotype of $B d$ on them. Thirty-three haplotypes were unique to the mainland of India and 19 to the Andaman and Nicobar islands. After their initial experiments showed poor performance of TaqMan quantitative PCR (qPCR) assay, a gold standard diagnostic assay for chytridiomycosis globally, they used Nested PCR assay following the protocol by Goka et al. ${ }^{26}$. Four novel haplotypes sequenced in this study had insertion-deletion mutations in the $B d$ diagnostic TaqMan probe binding sites and in the reverse priming site of the qPCR primers. They also went on to predict that the region could have $B d$ with 160 haplotypes. With high haplotype diversity and poor diagnostic assays, the study documented some patterns that were unprecedented and it drew the attention of researchers globally.

Three major clades of Asian ITS haplotypes have been identified, one that has pan-global distribution (India, China, Japan, Italy, South Africa, and USA); second clade with haplotypes from Korea, Japan, and Brazil; third clade consisted of haplotypes with mutations at the TaqMan probe binding site confined to India, China, and Japan. There were some that did not show any specific association. The most common haplotype IN02 from India formed a cluster with haplotypes from Italy, South Africa, USA, China, and Japan. Haplotypes IN14 and CN13 from India and China, respectively, clustered with global pandemic strain $B d$ JEL 423 . It became clear that Asia has several haplotypes and they are closely related to those found in other continents having chytridiomycosis hotspots.

Scattered evidence from India and other Asian coldspots prompts the following hypotheses: (1) majority of the strains of $B d$ involved in infection in Asia are enzootic; (2) improved detection assays for Asian $B d$ would lead to improved understanding of infection biology; (3) lack of die-offs, low prevalence and infection load and high haplotype diversity are common in coldspots and we coin the term "coldspot syndrome" to address this unified phenomenon, and the mechanisms causing them might have a common explanation.

\section{Research Gaps and Challenges in Studies on Chytridiomycosis in Asia} Some significant pointers on chytridiomycosis from coldspots: (1) diagnostic measures for $B d$ in Asia should be re-visited, because the TaqMan-based $\mathrm{qPCR}^{62}$ (the gold standard detection assay for $B d$ ), did not facilitate detection of some mutant $B d$ haplotypes from India; (2) There is an increasing trend in prevalence values of the infection from the first report. This might be because of increased sampling size which includes higher species richness as well as a shift from using TaqMan qPCR to Nested PCR which could have helped identification of $B d$ positive samples with better specificity; (3) $B d$ haplotypes causing infections in Asia are associated with $B d$ GPL. There is unrecognized and under-estimated $B d$ genetic diversity in Asia. There is also an existing void from many Asian countries like Bangladesh and Nepal and also regional biases from within even well-monitored countries ${ }^{63}$. These leads need to be followed up with further research. The different approaches that could be employed to improve our understanding of $B d$ infections from 'coldspots' are summarised in Fig. 1.

\subsection{Develop Efficient Detection Assays}

Global standards for efficiency of $B d$ detection assays are based on universality, affordability and 
Field based studies

Lab based studies

\begin{tabular}{|c|c|c|}
\hline \multirow{5}{*}{ Pathogen } & - Culturing of $\mathrm{Bd}$ & - Culturing of $\mathrm{Bd}$ \\
\hline & - Prevalence on host population & - Morphological studies \\
\hline & - Periodicity of infection & - Histological studies \\
\hline & - Persistence on host & - Genome sequencing \\
\hline & & - Microbial interactions \\
\hline \multirow{4}{*}{ Host } & - Survival & - Skin microbiome \\
\hline & - Population dynamics & - Immune response \\
\hline & - Behavioural adaptation & - Recovery rates \\
\hline & - Impact on ontogenic stages & - Transmission rates \\
\hline \multirow{3}{*}{ Environment } & - eDNA studies & - Limiting factors for Bd \\
\hline & - Ecological Niche Models & - Abiotic factors that influence infection \\
\hline & - Pathogen transmissibility & \\
\hline
\end{tabular}

Figure 1: Different field and lab based approaches to understand the amphibian-Bd interaction in 'coldspots'.

accuracy. Genetic diversity in $B d$ strains revealed in coldspots has challenged the standards set for genetic markers previously identified. The first step towards improved understanding of $B d$ is investment in development of new and efficient markers that are truly universal. With asymptomatic infections common in coldspots and low cost involved in screening large samples, genetic tools are indispensable as detection assays (Table 1). Other assays have inherent advantages and disadvantages and they could be employed in specific conditions (Table 1). Nested PCR is a reliable method for detection, but it is more expensive than qPCR. A challenge would be to develop a new qPCR marker that would detect Asian strains reliably.

\subsection{Epidemiological Studies}

Assessments on $B d$ prevalence in several parts of Asia are descriptive. They do not focus on aspects of the host or pathogen biology. Information regarding $B d$ pathogenesis that we presently know is because of studies on individual amphibians in laboratory conditions $\mathrm{s}^{3,6}$. These approaches should be used to understand the 'coldspot syndrome' in Asia and
elsewhere.A good example of such studies is in Bovo et al. ${ }^{64}$, where three species of Brazilian frogs were infected with an enzootic strain of $B d$. This study showed that enzootic strains might cause only sub-lethal infections; however, the skin resistance of the affected amphibians increased. This study also pointed out that sub-lethal infections varied in intensity by species. This probably means that while enzootic infections might not cause a staggering effect on the individual, it could affect the host's fitness and thereby influence survival. While knowledge on the fate of a host exposed to infection is important, the setting of such host-pathogen interactions would be most informative. To understand such factors, studies focussing on interactions between hosts showing a range of responses are required. At present, we have a poor understanding of the factors influencing survival of infected frogs in coldspots. Increased host diversity could lead to reduced impacts of the disease because of 'dilution effect' ${ }^{65}$. High host species richness might impede pathogen transmission as different species have specific responses to infection, creating a heterogeneous host assemblage for the pathogen to thrive on. Some studies of dilution effect in the amphibian-Bd system 


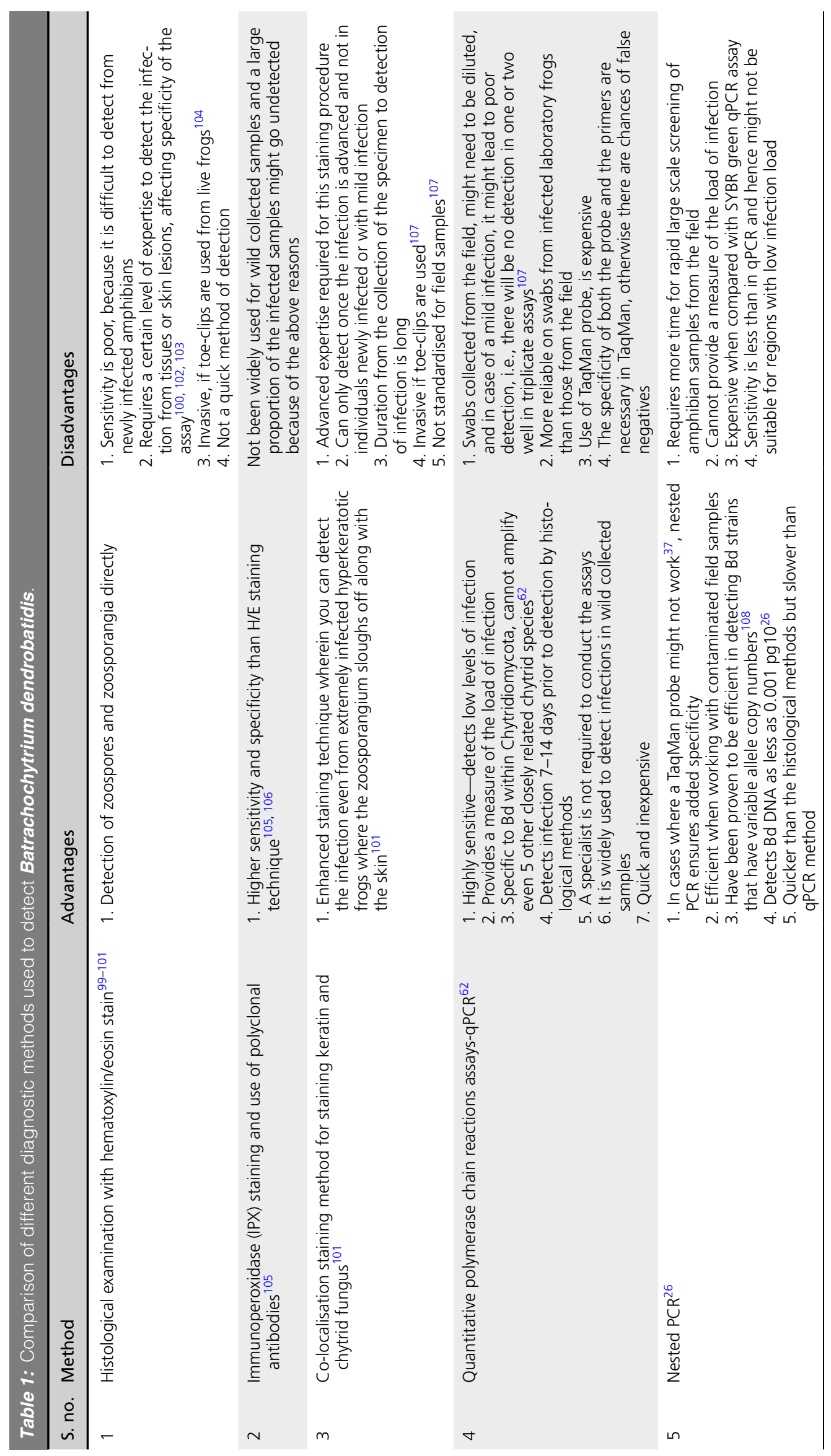




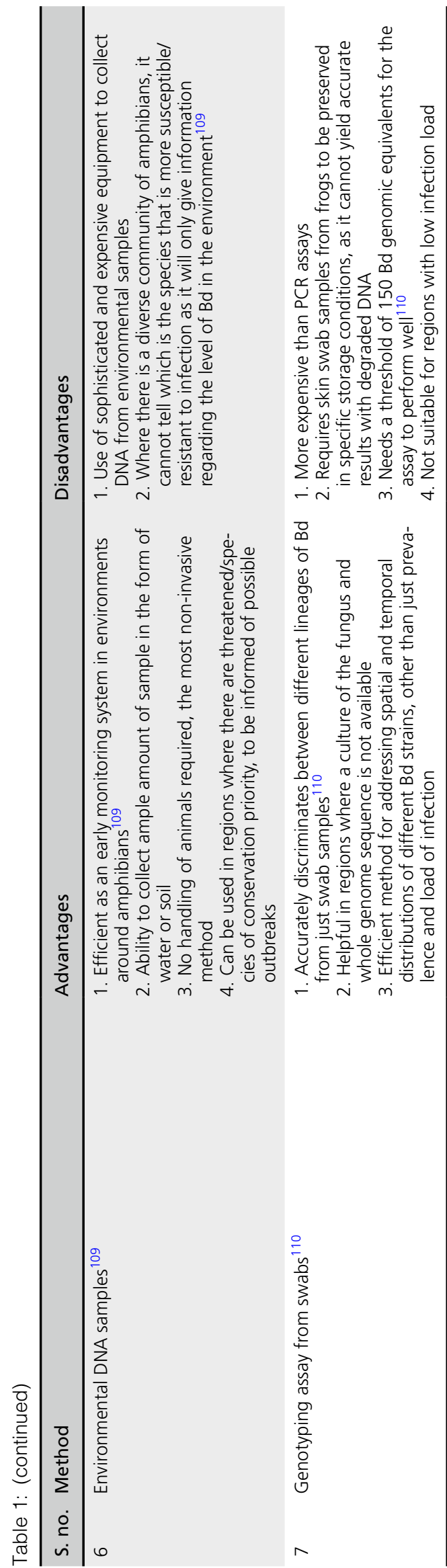

have shown that host diversity decreased risks of chytridiomycosis ${ }^{66-68}$, while others have showed that host diversity increased risks for infection ${ }^{69}$. Heterogeneity in resilience of $B d$ infection in frog species is not well understood. Some species that are 'super-shedders' of the chytrid zoospores, might facilitate a higher prevalence of infection and disease risks in that community. An example of this is Atelopus zeteki, which is highly susceptible to chytridiomycosis, that sheds chytrid zoospores in the environment, thus exposing sympatric species to infection risks ${ }^{7}$. Some frog species are known to serve as reservoirs of chytrid zoospores, like Lithobates catesbeianus and Xenopus laevis ${ }^{70,71}$. To understand the scale of infection in frog populations, infection histories of individual frogs, overall prevalence in the frog populations and recovery rates in infected individuals are vital parameters that need to be considered.

\subsection{Monitoring Host Populations}

Several amphibian population monitoring programmes are being actively pursued globally. Many amphibian monitoring programmes are designed for short-term or focused on single species. Asymptomatic infected frogs showed reduced fitness, skipped breeding events, or experienced die-offs during metamorphosis of infected larvae, causing population declines ${ }^{72-75}$. Tadpoles are especially vulnerable to $B d$ infection because their adaptive immune system shuts down during metamorphosis and a recovery from chytrid infection during this time could be difficult $^{76}$. Smaller frogs showed greater vulnerability to infection than large ones ${ }^{18}$. Latitude, elevation, and seasonality have varied influences prevalence and load of $B d$ in hotspots of infection ${ }^{17-19}$. In coldspots, seasonal fluctuation in $B d$ prevalence has been recorded ${ }^{29,30,38}$. Detection of these patterns at a population level and inferring infection by the pathogen requires appropriate designs of amphibian monitoring programs. While efforts are afoot in hotspots of infection, the need to establish such programs in coldspots of infection has not taken off. Both $\mathrm{NPH}$ and $\mathrm{EPH}$ predict that places with uncharacterised pathogen, and host diversity could become a dynamic front for evolution of new hybridised lineages of the pathogen which could have unpredictable disease outcomes ${ }^{21,50}$. With climate change impacts sweeping through natural ecosystems, there could be a spate of frog species that might need to be rescued by ex-situ interventions in future. Therefore, understanding 
susceptibility to infection in the context of the host community, pathogen strains, habitat, host life history, habitats and landscape parameters become necessary precursors for establishing ex-situ programmes ${ }^{84-86}$. Repeated observations made during monitoring have revealed behaviours in some frogs that resulted in recovery from chytrid infection ${ }^{37,87}$. Long-term population monitoring programmes should become an indispensable part of chytrid research, equitably in all regions of the world.

\subsection{Understanding Frog Defences}

There is also a growing body of research on amphibian skin microbiome and its impacts on disease persistence ${ }^{59,77-79}$. The skin microbiome forms the first line of defence by the innate immune system and the diversity of the microbial community helps clear infections before they cause pathogenesis by also producing antimicrobial peptides (AMPs) ${ }^{80,81}$. There are few studies from cold spots integrating the skin microbiome to chytridiomycosis research. Study on Bombina orientalis, found that there are diverse communities of microbes present on the ventral and dorsal surfaces of the frog skin which are different between the captive and wild toads ${ }^{78}$. Amphibians undergo a dramatic morphological and physiological change during metamorphosis. From a tadpole to an adult, there was a turnover of skin microbiomes which might have important survival outcomes against disease ${ }^{82}$. Amphibian species in communities occupy different niches and have diverse reproductive strategies. This presents a unique opportunity to explore the mechanisms that impart heterogeneity in host resilience. Coldspots from India have reported elevated levels of anti- $B d$ microbes on the skin of uninfected frogs that were terrestrial, arboreal, and aquatic ${ }^{83}$. This study shows a predominance of anti- $B d$ bacterial communities on six frogs $(51.7 \%)$, suggest the role of microbiome in offering resistance to $B d$ infections in them. This study spanned a narrow sample size, and more such studies covering more samples, both uninfected and mildly infected will throw more light on whether the presence of a mild $B d$ infection alters the microbiome at all. Such a knowledge gap compounds the already present voids in our comprehension of $B d$ 's pathogenesis in cold spots. At population levels, the host genotype also plays a major role in deciding disease impacts. For example, the alleles associated with the Major Histocompatibility Complex (MHC) which contribute to the adaptive immune response of the hosts, was reported to affect the resistance and survival to chytridiomycosis in Lithobates yavapaiensis ${ }^{32}$ and Littoria verreauxi $i^{84}$. These are yet unexplored though important areas to examine in communities of amphibians hosts in cold spots.

\subsection{Culturing of the Pathogen}

The most important step for in-depth studies of any disease is culturing and maintaining pathogens in controlled conditions. This is relatively easy when infected hosts are detected easily. $B d$ cultures are of considerable research value, as they have catalysed our understanding of origin, pathogenesis, virulence factors, phenotypic characters of the pathogen and other epidemiological parameters of the disease ${ }^{85-93}$. There is a disproportionately large number of $B d$ strains isolated and cultured in hotspots of infection than in Asian coldspots ${ }^{23}$.However, in cold spots, this task is challenging because infection on the hosts is not easily detected and the pathogen load in a frog is low. With few viable zoospores and the possibility of contamination with other fast-growing fungus, culturing attempts in Asian coldspots have often failed. Culturing protocol outlined for $B d$ by Longcore et al. ${ }^{3}$ relies on finding evidently infected hosts and also euthanizing them for isolation. This might not be a practical approach in coldspots because finding infected frogs is not easy. This is difficult in cold spots where you might have to sacrifice healthy individuals sometimes, because of their unidentified infection status. To confront this issue, Fisher 2012, designed non-lethal protocols for isolation which included collecting toe-clips and tissue specimens of individuals from the wild and using tadpoles as baits to isolate the chytrid fungus ${ }^{23,94}$. Tadpoles with a prolonged larval phase have a higher burden of infection ${ }^{95}$. Infection in tadpoles are recognized by hyperkeratosis and depigmentation especially in the keratinous jawsheaths of infected tadpoles ${ }^{74,96-98}$. Infected tadpoles can be used to extract the mouth parts while uninfected tadpoles can be used as live baits for infection, by co-housing with infected adult individuals ${ }^{29}$. This technique should be used in coldspots, as this method amplifies the number of zoospores. It is also important to perform repeated culturing experiments in different parts of coldspots. Oral deformities have been observed in Nasikabatrachus sahyadrensis larvae (Vasudevan personal communication), but such field observations on other species are not known. We suggest that reports from coldspots are important 
and it could provide valuable leads to successfully culture the enzootic $B d$.

\section{Conclusion}

Chytridiomycosis-induced amphibian declines have posed an unenviable challenge to batrachologists and conservation biologists globally. While the pathogen has swept through continents causing devastating impacts on amphibian populations, conservation biologists have been able to provide insight into the magnitude of the impact and suggest ways to ameliorate it. Some salient points have emerged from a large body of knowledge amassed over two and half decades. Amphibians living in the presence of $B d$ in the environment or on their body do not necessarily suffer from chytridiomycosis. After the onset of the disease, the desired outcome could be complete elimination of $B d$ from the frog population. It is not practical, as there are chances of pathogen re-emergence, which might cause far more serious impacts on the amphibian populations than in the first instance of emergence. It is important to understand the multi-faceted interaction between $B d$ and the amphibian, and to maintain a viable host population, even if they are $B d$-colonised ${ }^{85}$. Coldspots of infection present a scenario of a natural experiment unfolding where $B d$ is under selection pressure to cause infection and the hosts are under similar pressure to survive. Due attention must be given to understand the dynamics between the host and the pathogen. In coldspots, focussing on the role of ecological immunity through long-term monitoring of amphibian population is more important than on clearing infections. Leveraging research findings from coldspots of $B d$ infection is part of the grand challenge biologists are faced with at present. This requires large scale collaborative efforts. In the context of low number of systematic chytridiomycosis assessments from a highly diverse amphibian area, we have tried to highlight the caveats in existing methodologies and the emphasis on research in coldspots should be on: (1) ramping up culturing and genome sequencing of enzootic strains of $B d$; (2) understanding mechanisms that cause and maintain 'coldspot syndrome' in populations; (3) understanding the environmental, host defence and life history factors that clear infections or reduce zoospore loads on amphibians (4) establishing long-term monitoring stations in coldspots to gather longitudinal data on host-pathogen dynamics.

\section{Publisher's Note}

Springer Nature remains neutral with regard to jurisdictional claims in published maps and institutional affiliations.

\section{Acknowledgements}

We extend our sincere thanks to University Grants Commission for research fellowship to GS; Council for Scientific and Industrial Research institute Centre for Cellular and Molecular Biology-Hyderabad for generously supporting chytridiomycosis work at the Laboratory for the Conservation of Endangered Species. Wildlife Institute of India, Dehradun provided KV support for several projects in the field that allowed him to make observations on frogs throughout India.

Received: 14 January 2021 Accepted: 25 March 2021

Published online: 2 June 2021

\section{References}

1. Stuart SN, Chanson JS, Cox NA, Young BE, Rodrigues ASL, Fischman DL et al (2004) Status and trends of amphibian declines and extinctions worldwide. Science (New York, NY) 306:1783-1786. https://doi.org/10. 1126/science. 1103538

2. Lips KR, Brem F, Brenes R, Reeve JD, Alford RA, Voyles $\mathrm{J}$ et al (2006) Emerging infectious disease and the loss of biodiversity in a Neotropical amphibian community. Proc Natl Acad Sci USA 103:3165-3170. https://doi.org/ 10.1073/pnas.0506889103

3. Longcore JE, Pessier AP, Nichols DK (1999) (1999) Batrachochytrium dendrobatidis gen. et sp. nov., a chytrid pathogenic to amphibians. Mycologia 91:219227. https://doi.org/10.1080/00275514.1999.12061011

4. Gascon C, Collins JP, Moore RD, Church DR, Mckay JE, Mendelson III JR (2005) Amphibian conservation action plan. In: IUCN/SSC Amphibian Specialist Group. Gland, Switzerland and Cambridge, UK, p 64

5. Scheele BC, Pasmans F, Skerratt LF, Berger L, Martel A, Beukema W et al (2019) Amphibian fungal panzootic causes catastrophic and ongoing loss of biodiversity. Science 363:1459-1463. https://doi.org/10.1126/science. aav0379

6. Berger L, Hyatt AD, Speare R, Longcore JE (2005) Life cycle stages of the amphibian chytrid Batrachochytrium dendrobatidis. Dis Aquat Org 68:51-63. https://doi.org/ 10.3354/dao068051

7. DiRenzo GV, Langhammer PF, Zamudio KR, Lips KR (2014) Fungal infection intensity and zoospore output of Atelopus zeteki, a potential acute chytrid supershedder. PLoS ONE 9:1-6. https://doi.org/10.1371/journal. pone.0093356 
8. James TY, Kauff F, Schoch CL, Matheny PB, Hofstetter V, Cox CJ et al (2006) Reconstructing the early evolution of Fungi using a six-gene phylogeny. Nature 443:818-822. https://doi.org/10.1038/nature05110

9. Skerratt LF, Berger L, Speare R, Cashins S, McDonald KR, Phillott AD et al (2007) Spread of chytridiomycosis has caused the rapid global decline and extinction of frogs. EcoHealth 4:125-134. https://doi.org/10.1007/ s10393-007-0093-5

10. Rachowicz LJ, Hero JM, Alford RA, Taylor JW, Morgan JAT, Vredenburg VT et al (2005) The novel and endemic pathogen hypotheses: competing explanations for the origin of emerging infectious diseases of wildlife. Conserv Biol 19:1441-1448. https://doi.org/10.1111/j.15231739.2005.00255.x

11. Mazzoni R, Cunningham AA, Daszak P, Apolo A, Perdomo E, Speranza G (2003) Emerging pathogen of wild amphibians in frogs (Rana catesbeiana) farmed for international trade. Emerg Infect Dis 9:995-998. https://doi.org/10.3201/eid0908.030030

12. Weldon C, du Preez LH, Hyatt AD, Muller R, Speare R (2004) Origin of the amphibian chytrid fungus. Emerg Infect Dis 10:2100-2105. https://doi.org/10. 3201/eid1012.030804

13. Garner TWJ, Perkins MW, Govindarajulu P, Seglie D, Walker S, Cunningham AA et al (2006) The emerging amphibian pathogen Batrachochytrium dendrobatidis globally infects introduced populations of the North American bullfrog, Rana catesbeiana. Biol Lett 2:455459. https://doi.org/10.1098/rsbl.2006.0494

14. Morehouse EA, James TY, Ganley ARD, Vilgalys R, Berger L, Murphy PJ et al (2003) Multilocus sequence typing suggests the chytrid pathogen of amphibians is a recently emerged clone. Mol Ecol 12:395-403. https:// doi.org/10.1046/j.1365-294X.2003.01732.x

15. Reading CJ (2007) Linking global warming to amphibian declines through its effects on female body condition and survivorship. Oecologia 151:125-131. https:// doi.org/10.1007/s00442-006-0558-1

16. Bosch J, Martínez-Solano I (2006) Chytrid fungus infection related to unusual mortalities of Salamandra salamandra and Bufo bufo in the Peñalara Natural Park, Spain. Oryx 40:84-89. https://doi.org/10.1017/S0030 605306000093

17. Kriger KM, Hero JM (2006) Survivorship in wild frogs infected with chytridiomycosis. EcoHealth 3:171-177. https://doi.org/10.1007/s10393-006-0027-7

18. Kriger KM, Pereoglou F, Hero JM (2007) Latitudinal variation in the prevalence and intensity of chytrid (Batrachochytrium dendrobatidis) infection in eastern Australia. Conserv Biol 21:1280-1290. https://doi.org/ 10.1111/j.1523-1739.2007.00777.x

19. Kriger KM, Hero JM (2008) Altitudinal distribution of chytrid (Batrachochytrium dendrobatidis) infection in subtropical Australian frogs. Aust Ecol 33:1022-1032. https://doi.org/10.1111/j.1442-9993.2008.01872.x
20. Drew A, Allen EJ, Allen LJS (2006) Analysis of climatic and geographic factors affecting the presence of chytridiomycosis in Australia. Dis Aquat Org 68:245250. https://doi.org/10.3354/dao068245

21. O’Hanlon SJ, Rieux A, Farrer RA, Rosa GM, Waldman B, Bataille A et al (2018) Recent Asian origin of chytrid fungi causing global amphibian declines. Science 360:621-627. https://doi.org/10.1126/science.aar1965

22. Olson DY, Ronnenberg K (2014) Mapping project: 2014 update. FrogLog 22:17-21

23. Fisher MC, Ghosh P, Shelton JMG, Bates K, Brookes L, Wierzbicki C et al (2018) Development and worldwide use of non-lethal, and minimal populationlevel impact, protocols for the isolation of amphibian chytrid fungi. Sci Rep 8:4-11. https://doi.org/10.1038/ s41598-018-24472-2

24. Fisher MC, Garner TWJ (2020) Chytrid fungi and global amphibian declines. Nat Rev Microbiol 18:332343. https://doi.org/10.1038/s41579-020-0335-x

25. Une Y, Kadekaru S, Tamukai K, Goka K, Kuroki T (2008) First report of spontaneous chytridiomycosis in frogs in Asia. Dis Aquat Org 82:157-160. https://doi. org/10.3354/dao02006

26. Goka K, Yokoyama J, Une Y, Kuroki T, Suzuki K, Nakahara M et al (2009) Amphibian chytridiomycosis in Japan: distribution, haplotypes and possible route of entry into Japan. Mol Ecol 18:4757-4774. https://doi. org/10.1111/j.1365-294X.2009.04384.x

27. Bai C, Garner TWJ, Li Y (2010) First evidence of batrachochytrium dendrobatidis in China: discovery of chytridiomycosis in introduced American bullfrogs and native amphibians in the Yunnan Province, China. EcoHealth 7:127-134. https://doi.org/10.1007/ s10393-010-0307-0

28. Bai C, Liu X, Fisher MC, Garner TWJ, Li Y (2012) Global and endemic Asian lineages of the emerging pathogenic fungus Batrachochytrium dendrobatidis widely infect amphibians in China. Divers Distrib 18:307-318. https://doi.org/10.1111/j.1472-4642.2011. 00878.x

29. Bataille A, Fong JJ, Cha M, Wogan GOU, Baek HJ, Lee $\mathrm{H}$ et al (2013) Genetic evidence for a high diversity and wide distribution of endemic strains of the pathogenic chytrid fungus Batrachochytrium dendrobatidis in wild Asian amphibians. Mol Ecol 22:4196-4209. https://doi. org/10.1111/mec.12385

30. Fong JJ, Cheng TL, Bataille A, Pessier AP, Waldman B, Vredenburg VT (2015) Early 1900s detection of Batrachochytrium dendrobatidis in Korean amphibians. PLoS ONE 10:1-8. https://doi.org/10.1371/journal.pone. 0115656

31. Kusrini MD, Skerratt LF, Garland S, Berger L, Endarwin W (2008) Chytridiomycosis in frogs of Mount Gede Pangrango, Indonesia. Dis Aquat Org 82:187-194. https://doi.org/10.3354/dao01981 
32. Savage AE, Sredl MJ, Zamudio KR (2011) Disease dynamics vary spatially and temporally in a North American amphibian. Biol Conserv 144:1910-1915. https://doi.org/10.1016/j.biocon.2011.03.018

33. Nair A, Olivia D, Gopalan SV, George S, Kumar SK, Merila J et al (2011) Herpetological review infectious disease screening of Indirana frogs from the. Herpetol Rev 42:554-557

34. Dahanukar N, Krutha K, Paingankar MS, Padhye AD, Modak N, Molur S (2013) Endemic Asian chytrid strain infection in threatened and endemic anurans of the Northern Western Ghats, India. PLoS ONE 8:1-8. https://doi.org/10.1371/journal.pone.0077528

35. Rowley JJL, Alford RA (2013) Hot bodies protect amphibians against chytrid infection in nature. Sci Rep 3:1515. https://doi.org/10.1038/srep01515

36. Molur S, Krutha K, Paingankar MS, Dahanukar N (2015) Asian strain of Batrachochytrium dendrobatidis is widespread in the Western Ghats, India. Dis Aquat Org 112:251-255. https://doi.org/10.3354/dao02804

37. Mutnale MC, Anand S, Eluvathingal LM, Roy JK, Reddy GS, Vasudevan K (2018) Enzootic frog pathogen Batrachochytrium dendrobatidis in Asian tropics reveals high ITS haplotype diversity and low prevalence. Sci Rep 8:10125. https://doi.org/10.1038/ s41598-018-28304-1

38. Thorpe CJ, Lewis TR, Fisher MC, Wierzbicki CJ, Kulkarni S, Pryce D et al (2018) Climate structuring of Batrachochytrium dendrobatidis infection in the threatened amphibians of the northern Western Ghats, India. R Soc Open Sci 5:180211. https://doi. org/10.1098/rsos.180211

39. James TY, Toledo LF, Rödder D, Silva Leite D, Belasen AM, Betancourt-Román CM et al (2015) Disentangling host, pathogen, and environmental determinants of a recently emerged wildlife disease: lessons from the first 15 years of amphibian chytridiomycosis research. Ecol Evol 5:4079-4097. https://doi.org/10. 1002/ece3.1672

40. Swei A, Rowley JJL, Rödder D, Diesmos MLL, Diesmos AC, Briggs CJ et al (2011) Is chytridiomycosis an emerging infectious disease in Asia? PLoS ONE 6:e23179. https://doi.org/10.1371/journal.pone.00231 79

41. Vredenburg VT, Knapp RA, Tunstall TS, Briggs CJ (2010) Dynamics of an emerging disease drive largescale amphibian population extinctions. Proc Natl Acad Sci USA 107:9689-9694. https://doi.org/10. 1073/pnas.0914111107

42. Rödder D, Kielgast J, Lötters S (2010) Future potential distribution of the emerging amphibian chytrid fungus under anthropogenic climate change. Dis Aquat Org 92:201-207. https://doi.org/10.3354/dao02197

43. Lips KR, Diffendorfer J, Mendelson JR, Sears MW (2008) Riding the wave: reconciling the roles of disease and climate change in amphibian declines. PLoS
Biol 6:0441-0454. https://doi.org/10.1371/journal.pbio. 0060072

44. Rodriguez D, Becker CG, Pupin NC, Haddad CFB, Zamudio KR (2014) Long-term endemism of two highly divergent lineages of the amphibian-killing fungus in the Atlantic Forest of Brazil. Mol Ecol 23:774787. https://doi.org/10.1111/mec.12615

45. Talley BL, Muletz CR, Vredenburg VT, Fleischer RC, Lips KR (2015) A century of Batrachochytrium dendrobatidis in Illinois amphibians (1888-1989). Biol Conserv 182:254-261. https://doi.org/10.1016/j.biocon. 2014.12.007

46. Farrer RA, Weinert LA, Bielby J, Garner TWJ, Balloux F, Clare F et al (2011) Multiple emergences of genetically diverse amphibian-infecting chytrids include a globalized hypervirulent recombinant lineage. Proc Natl Acad Sci USA 108:18732-18736. https://doi.org/ 10.1073/pnas.1111915108

47. Rosenblum EB, James TY, Zamudio KR, Poorten TJ, Ilut D, Rodriguez D et al (2013) Complex history of the amphibian-killing chytrid fungus revealed with genome resequencing data. Proc Natl Acad Sci USA 110:93859390. https://doi.org/10.1073/pnas.1300130110

48. Morgan JAT, Vredenburg VT, Rachowicz LJ, Knapp RA, Stice MJ, Tunstall T et al (2007) Population genetics of the frog-killing fungus Batrachochytrium dendrobatidis. Proc Natl Acad Sci USA 104:13845-13850. https://doi. org/10.1073/pnas.0701838104

49. Schloegel LM, Toledo LF, Longcore JE, Greenspan SE, Vieira CA, Lee M et al (2012) Novel, panzootic and hybrid genotypes of amphibian chytridiomycosis associated with the bullfrog trade. Mol Ecol 21:5162-5177. https://doi.org/10.1111/j.1365-294X.2012.05710.x

50. Byrne AQ, Vredenburg VT, Martel A, Pasmans F, Bell RC, Blackburn DC et al (2019) Cryptic diversity of a widespread global pathogen reveals expanded threats to amphibian conservation. Proc Natl Acad Sci USA 116:20382-20387. https://doi.org/10.1073/pnas.19082 89116

51. Catenazzi A (2015) State of the World's amphibians. Annu Rev Environ Resour 40:91-119. https://doi.org/ 10.1146/annurev-environ-102014-021358

52. Carpenter AI, Andreone F, Moore RD, Griffiths RA (2014) A review of the international trade in amphibians: the types, levels and dynamics of trade in CITESlisted species. Oryx 48:565-574. https://doi.org/10. 1017/S0030605312001627

53. Mohanty NP, Measey J (2019) The global pet trade in amphibians: species traits, taxonomic bias, and future directions. Biodivers Conserv 28:3915-3923. https:// doi.org/10.1007/s10531-019-01857-x

54. Walker SF, Bosch J, James TY, Litvintseva AP, Oliver Valls JA, Piña S et al (2008) Invasive pathogens threaten species recovery programs. Curr Biol 18:853-854. https://doi.org/10.1016/j.cub.2008.07.033 
55. Wombwell EL, Garner TWJ, Cunningham AA, Quest R, Pritchard S, Rowcliffe JM et al (2016) Detection of Batrachochytrium dendrobatidis in amphibians imported into the UK for the pet trade. EcoHealth 13:456-466. https://doi.org/10.1007/s10393-016-1138-4

56. Fu M, Waldman B (2019) Ancestral chytrid pathogen remains hypervirulent following its long coevolution with amphibian hosts. Proc R Soc B Biol Sci 286:1-9. https://doi.org/10.1098/rspb.2019.0833

57. Savage AE, Zamudio KR (2016) Adaptive tolerance to a pathogenic fungus drives major histocompatibility complex evolution in natural amphibian populations. Proc R Socy B Biol Sci 283:20153115. https://doi.org/ 10.1098/rspb.2015.3115

58. Refsnider JM, Poorten TJ, Langhammer PF, Burrowes PA, Rosenblum EB (2015) Genomic correlates of virulence attenuation in the deadly amphibian chytrid fungus, Batrachochytrium dendrobatidis. G3 Genes Genomes Genet 5:2291-2298. https://doi.org/10.1534/ g3.115.021808

59. Bates KA, Clare FC, O’Hanlon S, Bosch J, Brookes L, Hopkins K et al (2018) Amphibian chytridiomycosis outbreak dynamics are linked with host skin bacterial community structure. Nat Commun 9:1-11. https:// doi.org/10.1038/s41467-018-02967-w

60. Deepak P, Dinesh KP, Prasad VK, Das A, Ashadevi JS (2020) Distribution status of the Western burrowing frog, Sphaerotheca pashchima in India. Zootaxa 4894:146-150. https://doi.org/10.11646/zootaxa.4894.1. 10

61. Kamei RG, Gower DJ, Wilkinson M, Biju SD (2013) Systematics of the caecilian family chikilidae (Amphibia: Gymnophiona) with the description of three new species of chikila from northeast India. Zootaxa 3666:401435. https://doi.org/10.11646/zootaxa.3666.4.1

62. Boyle DG, Boyle DB, Olsen V, Morgan JAT, Hyatt AD (2004) (2004) Rapid quantitative detection of chytridiomycosis (Batrachochytrium dendrobatidis) in amphibian samples using real-time Taqman PCR assay. Dis Aquat Org 60:141-148. https://doi.org/10.3354/dao06 0141

63. Rahman MM, Badhon MK, Salauddin M, Rabbe MF, Islam MS (2020) Chytrid infection in asia: how much do we know and what else do we need to know? Herpetol J 30:99-111. https://doi.org/10.33256/hj30.2.99111

64. Bovo RP, Andrade DV, Toledo LF, Longo AV, Rodriguez D, Haddad CFB et al (2016) Physiological responses of Brazilian amphibians to an enzootic infection of the chytrid fungus Batrachochytrium dendrobatidis. Dis Aquat Org 117:245-252. https://doi.org/10.3354/dao02 940

65. Keesing F, Holt RD, Ostfeld RS (2006) Effects of species diversity on disease risk. Ecol Lett 9:485-498. https:// doi.org/10.1111/j.1461-0248.2006.00885.x

66. Searle CL, Biga LM, Spatafora JW, Blaustein AR (2011) A dilution effect in the emerging amphibian pathogen
Batrachochytrium dendrobatidis. Proc Natl Acad Sci USA 108:16322-16326. https://doi.org/10.1073/pnas. 1108490108

67. Guilherme Becker C, Rodriguez D, Felipe Toledo L, Longo AV, Lambertini C, Corrêa DT et al (2014) Partitioning the net effect of host diversity on an emerging amphibian pathogen. Proc R Soc B Biol Sci 281:1-7. https://doi.org/10.1098/rspb.2014.1796

68. Venesky MD, Raffel TR, Mcmahon TA, Rohr JR (2014) Confronting inconsistencies in the amphibian-chytridiomycosis system: Implications for disease management. Biol Rev 89:477-483. https://doi.org/10.1111/brv.12064

69. Becker CG, Zamudio KR (2011) Tropical amphibian populations experience higher disease risk in natural habitats. Proc Natl Acad Sci USA 108:9893-9898. https://doi.org/10.1073/pnas.1014497108

70. Daszak P, Cunningham AA, Hyatt AD (2001) Anthropogenic environmental change and the emergence of infectious diseases in wildlife. Acta Trop 78:103-116. https://doi.org/10.1016/S0001-706X(00)00179-0

71. Vredenburg VT, Felt SA, Morgan EC, McNally SVG, Wilson S, Green SL (2013) Prevalence of Batrachochytrium dendrobatidis in xenopus collected in Africa (1871-2000) and in California (2001-2010). PLoS ONE 8:6-9. https://doi.org/10.1371/journal.pone. 0063791

72. Briggs CJ, Vredenburg VT, Knapp RA, Rachowicz LJ (2005) Investigating the population-level effects of chytridiomycosis: an emerging infectious disease of amphibians. Ecology 86:3149-3159. https://doi.org/10. 1890/04-1428

73. Knapp RA, Morgan JAT (2006) Tadpole mouthpart depigmentation as an accurate indicator of chytridiomycosis, an emerging disease of amphibians. Copeia 2006:188-197. https://doi.org/10.1643/00458511(2006)6[188:TMDAAA]2.0.CO;2

74. Fellers GM, Green ED, Longcore JE (2001) Oral chytridiomycosis in the mountain yellow-legged frog (Rana muscosa). Copeia 2001:945-953. https://doi.org/ 10.1643/0045-8511(2001)001[0945:OCITMY]2.0.CO;2

75. Blaustein AR, Romansic JM, Scheessele EA, Han BA, Pessier AP, Longcore JE (2005) Interspecific variation in susceptibility of frog tadpoles to the pathogenic fungus Batrachochytrium dendrobatidis. Conserv Biol 19:14601468. https://doi.org/10.1111/j.1523-1739.2005.00195.x

76. Rollins-Smith LA (1998) Metamorphosis and the amphibian immune system. Immunol Rev 166:221230. https://doi.org/10.1111/j.1600-065X.1998.tb012 65.x

77. Rebollar EA, Martínez-Ugalde E, Orta AH (2020) The amphibian skin microbiome and its protective role against chytridiomycosis. Herpetologica 76:167-177. https://doi.org/10.1655/0018-0831-76.2.167

78. Bataille A, Lee-Cruz L, Tripathi B, Kim H, Waldman B (2015) Microbiome variation across amphibian skin regions: implications for chytridiomycosis mitigation 
efforts. Microb Ecol 71:221-232. https://doi.org/10. 1007/s00248-015-0653-0

79. Vredenburg VT, Briggs CJ, Harris RN (2011) Hostpathogen dynamics of amphibian chytridiomycosis: the role of the skin microbiome in health and disease. Fungal diseases: an emerging threat to human, animal, and plant health. National Academy Press, Washington, DC, pp 342-355

80. Becker MH, Walke JB, Cikanek S, Savage AE, Mattheus N, Santiago CN et al (2015) Composition of symbiotic bacteria predicts survival in Panamanian golden frogs infected with a lethal fungus. Proc R Soc B Biol Sci 282:1-9. https://doi.org/10.1098/rspb.2014.2881

81. Loudon AH, Venkataraman A, Van Treuren W, Woodhams DC, Parfrey LW, McKenzie VJ et al (2016) Vertebrate hosts as Islands: dynamics of selection, immigration, loss, persistence, and potential function of bacteria on salamander skin. Front Microbiol 7:1-11. https:// doi.org/10.3389/fmicb.2016.00333

82. Bataille A, Lee-Cruz L, Tripathi B, Waldman B (2018) Skin bacterial community reorganization following metamorphosis of the fire-bellied toad (Bombina orientalis). Microb Ecol 75:505-514. https://doi.org/10.1007/ s00248-017-1034-7

83. Mutnale MC, Reddy GS, Vasudevan K (2021) Bacterial community in the skin microbiome of frogs in a coldspot of chytridiomycosis infection. Microb Ecol. https:// doi.org/10.1007/s00248-020-01669-5

84. Bataille A, Cashins SD, Grogan L, Skerratt LF, Hunter D, McFadden $M$ et al (2015) Susceptibility of amphibians to chytridiomycosis is associated with MHC class II conformation. Proc R Soc B Biol Sci 282:20143127. https://doi.org/10.1098/rspb.2014.3127

85. Voyles J, Berger L, Young S, Speare R, Webb R, Warner $\mathrm{J}$ et al (2007) Electrolyte depletion and osmotic imbalance in amphibians with chytridiomycosis. Dis Aquat Org 77:113-118. https://doi.org/10.3354/dao01838

86. Farrer RA, Martel A, Verbrugghe E, Abouelleil A, Ducatelle R, Longcore JE et al (2017) Genomic innovations linked to infection strategies across emerging pathogenic chytrid fungi. Nat Commun. https://doi.org/10. 1038/ncomms 14742

87. Rosenblum EB, Poorten TJ, Joneson S, Settles M (2012) Substrate-specific gene expression in Batrachochytrium dendrobatidis, the chytrid pathogen of amphibians. PLoS ONE 7:1-10. https://doi.org/10.1371/journal. pone.0049924

88. Piotrowski JS, Annis SL, Longcore JE (2004) Physiology of Batrachochytrium dendrobatidis, a chytrid pathogen of amphibians. Mycologia 96:9. https://doi.org/10.2307/ 3761981

89. Fisher MC, Bosch J, Yin Z, Stead DA, Walker J, Selway L et al (2009) Proteomic and phenotypic profiling of the amphibian pathogen Batrachochytrium dendrobatidis shows that genotype is linked to virulence. Mol Ecol
18:415-429. https://doi.org/10.1111/j.1365-294X.2008. 04041.x

90. Becker CG, Greenspan SE, Tracy KE, Dash JA, Lambertini C, Jenkinson TS et al (2017) Variation in phenotype and virulence among enzootic and panzootic amphibian chytrid lineages. Fungal Ecol 26:45-50. https://doi. org/10.1016/j.funeco.2016.11.007

91. Garner TWJ, Walker S, Bosch J, Leech S, Rowcliffe JM, Cunningham AA et al (2009) Life history tradeoffs influence mortality associated with the amphibian pathogen Batrachochytrium dendrobatidis. Oikos 118:783-791. https://doi.org/10.1111/j.1600-0706.2008. 17202.x

92. Rosenblum EB, Poorten TJ, Settles M, Murdoch GK (2012) Only skin deep: shared genetic response to the deadly chytrid fungus in susceptible frog species. Mol Ecol 21:3110-3120. https://doi.org/10.1111/j.1365294X.2012.05481.x

93. Ribas L, Li M-S, Doddington BJ, Robert J, Seidel JA, Kroll JS et al (2009) Expression profiling the temperature-dependent amphibian response to infection by Batrachochytrium dendrobatidis. PLoS ONE 4:e8408. https://doi.org/10.1371/journal.pone.0008408

94. Fisher MC, Schmeller DS, Bosch J, Aanensen DM, Garner TWJ (2012) (2012) RACE: risk assessment of chytridiomycosis to European amphibian biodiversity. FrogLog 101:45-47

95. Skerratt LF, Berger L, Hines HB, McDonald KR, Mendez D, Speare R (2008) Survey protocol for detecting chytridiomycosis in all Australian frog populations. Dis Aquat Org 80:85-94. https://doi.org/10.3354/dao01923

96. Smith KG, Weldon C, Conradie W, Du Preez LH (2007) Relationships among size, development, and Batrachochytrium dendrobatidis infection in African tadpoles. Dis Aquat Org 74:159-164. https://doi.org/10.3354/ dao074159

97. Navarro-Lozano A, Sánchez-Domene D, Rossa-Feres DC, Bosch J, Sawaya RJ (2018) Are oral deformities in tadpoles accurate indicators of anuran chytridiomycosis? PLoS ONE 13:1-9. https://doi.org/10.1371/journal. pone. 0190955

98. Marantelli G, Berger L, Speare R, Keegan L (2004) Distribution of the amphibian chytrid Batrachochytrium dendrobatidis and keratin during tadpole development. Pac Conserv Biol 10:173-179. https://doi.org/10.1071/ pc040173

99. Aplin K, Kirkpatrick P (1999) Progress report on investigations into chytrid fungal outbreak in Western Australia.Perth: Western Australia Museaum

100. Berger L, Speare R, Daszak P, Green DE, Cunningham AA, Goggin CL et al (1998) Chytridiomycosis causes amphibian mortality associated with population declines in the rain forests of Australia and Central America. Proc Natl Acad Sci 95:9031-9036. https://doi. org/10.1073/pnas.95.15.9031 
101. Berger L, Speare R, Hyatt A (1999) Chytrid fungi and amphibian declines: overview, implications and future directions. In: Campbell A (ed) Declines and disappearances of Australian frogs. Environment Australia, Canberra, pp 23-33

102. Aplin K (2000) Chytridiomycosis in southwest Australia: historical sampling documents the date of introduction, rates of spread and seasonal epidemiology, and sheds new light on chytrid ecology. In: In Getting the Jump! on amphibian disease: conference and workshop compendium. Cairns, August 2000

103. Olsen V, Hyatt AD, Boyle DG, Mendez D (2004) Colocalisation of Batrachochytrium dendrobatidis and keratin for enhanced diagnosis of chytridiomycosis in frogs. Dis Aquat Org 61:85-88. https://doi.org/10.3354/ dao061085

104. McCarthy MA, Parris KM (2004) Clarifying the effect of toe clipping on frogs with Bayesian statistics. J Appl Ecol 41:780-786. https://doi.org/10.1111/j.0021-8901. 2004.00919.x

105. Berger L, Hyatt A, Olsen V, Hengstberger S, Boyle D, Marantelli G et al (2002) Production of polyclonal antibodies to Batrachochytrium dendrobatidis and their use in an immunoperoxidase test for chytridiomycosis in amphibians. Dis Aquat Org 48:213-220. https://doi.org/ 10.3354/dao048213

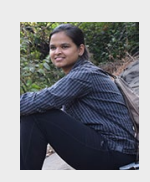

Gayathri Sreedharan finished her graduate and postgraduate studies in Microbiology from Amrita Vishwa Vidyapeetham, Kollam, Kerala, between 2010 and 2015. She has been keen on ecological and evolutionary questions pertaining to animal societies from her masters. She chose to work on the host-pathogen dynamics of Batrachochytrium dendrobatidis (Bd) and amphibians in Northern Western Ghats for her Ph.D. This work is among the first in the country to investigate individual and population-level outcomes of an enzootic pathogen using capture-mark-recapture models on frog populations.
106. Waldman B, Van De Wolfshaar KE (2001) Chytridiomycosis in New Zealand frogs. Surveillance 28:9-11

107. Kriger K, Hines H, Hyatt A, Boyle D, Hero J (2006) Techniques for detecting chytridiomycosis in wild frogs: comparing histology with real-time Taqman PCR. Dis Aquat Org 71:141-148. https://doi.org/10.3354/dao07 1141

108. Shin J, Bataille A, Kosch TA, Waldman B (2014) Swabbing often fails to detect amphibian chytridiomycosis under conditions of low infection load. PLoS ONE 9:e111091. https://doi.org/10.1371/journal.pone.01110 91

109. Kamoroff C, Goldberg C (2017) Using environmental DNA for early detection of amphibian chytrid fungus Batrachochytrium dendrobatidis prior to a ranid dieoff. Dis Aquat Org 127:75-79. https://doi.org/10.3354/ dao03183

110. Byrne AQ, Rothstein AP, Poorten TJ, Erens J, Settles ML, Rosenblum EB (2017) Unlocking the story in the swab: a new genotyping assay for the amphibian chytrid fungus Batrachochytrium dendrobatidis. Mol Ecol Resour 17:1283-1292. https://doi.org/10.1111/1755-0998. 12675

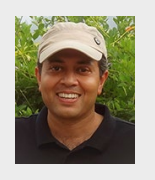

Karthikeyan Vasudevan is interested in biology of amphibians and has spent two decades on different aspects of research on the ecology of south Asian amphibians. He is the Co-Chair of IUCN's Amphibian Specialist Group for south Asia region and contributes to conservation efforts. Asian amphibian chytridiomycosis is a topic of research in his lab where he is working to reveal interesting aspects of the pathogen-host-environment interactions. 